\title{
Campylobacter Jejuni Infection in Broilers
}

\author{
Mohamed Shaker Abdel Hafez $^{1 *}$, Nagwa Thabet El-Shraway ${ }^{2}$ \\ ${ }^{1}$ Poultry Diseases Department, Faculty of Veterinary Medicine, New-Vally University, Egypt \\ ${ }^{2}$ Food Hygiene Department, Faculty of Veterinary Medicine, New-Vally University, Egypt
}

*Corresponding Author: Mohamed Shaker Abdel Hafez, Poultry Diseases Department, Faculty of Veterinary Medicine, New-Vally University, Egypt. Email: moemenassiut@ hotmail.com

\begin{abstract}
This study was aimed to assess the presence of Campylobacter jejuni infection and some of its virulence genes in broiler chickens in New Valley and Asyut provinces, Egypt. The study was conducted on 200 broiler chicken samples which obtained from 12 broiler flocks representing 60000 birds. One hundred intestinal samples and one hundred liver samples from birds (dead and live broilers suffering from diarrhea) during spring and summer seasons of 2016were used for bacteriological and molecular examinations. The isolated and identified strains were examined for the presence of virulence factors (VirB11, flaA and Iam genes). Results showed that out of 200 intestinal and liver samples, C. jejuni was isolated in 51 (25.5\%). The highest microbial load was in intestinal samples $(26 \%)$ followed by liver samples $(25 \%)$. In addition, the virulence genes of $C$. jejuni were identified in broiler chicken samples as ViroB11 (10\%), flaA gene (5\%) and Iam gene (40\%). In conclusion, this study revealed that $C$. jejuni may represent a threat to poultry production.
\end{abstract}

Keywords: broiler chickens, Campylobacter jejuni, virulence genes, PCR.

\section{INTRODUCTION}

Poultry houses can be contaminated by Campylobacter in many different methods from various environmental sources, making the control of flock colonization by Campylobacter a very challenging mission. At present, no single measure is completely effective in minimizing Campylobacter infections on poultry farms.

Campylobacter can break through biosecurity barriers and attack poultry houses, colonizing the chicken intestine and quickly multiplying in the intestinal mucosa. However, Campylobacter does not induce health or welfare troubles in chickens. Campylobacter spreads fast within broiler flocks and almost all birds will be infected within seven days (Garcia Ana et el.,).

Poultry flocks can be infected by multiple sources; it is difficult to eliminate Campylobacter from poultry farms by biosecurity measures alone. The use of fly screens on poultry farms has been found to be an effective method to decrease the introduction of Campylobacter into broiler farms especially during summer period.

The exact mechanism by which C.jejuniis introduced into the poultry farm still unclear, although a variety of important sources have been incriminated, including water (Pearson et al., 1993), insects(Rosef and Kapperud 1983),farm personnel, and rodents(Annan-Prah and Janc
1988). Regardless of the source, once $C$. jejuniis introduced into a poultry flock, it spreads quickly and usually contaminating the entire flock (Shanker et al.,1990).

One of the challenges associated with campylobacteriosis control is that Campylobacter behaves as a commensal micro-organism in healthy poultry flocks without causing any clinical symptoms. It is a normal inhabitant in the mucus layer of the cecum but does not penetrate the intestinal cells (Wael Abdelrahman 2014).

The persistence of C.jejuni during successive broiler flock rotations was suggested to be a result of the survival of the organism in many vectors as rodents and insects that were able to evacuate the house during cleaning and disinfection and then come back. However, no direct evidence mentioned to prove this opinion.

Other farm animals in broiler farms including pigs, cattle, sheep, and poultry other than chickens has been found to be associated with an increased risk of Campylobacter infection in broiler chickens.

In a follow up study, $C$.jejuni isolates from cattle were shown to have the same flaA type gene as the isolates from the broilers on the same farm.

C. jejuni is the major pathogen causing food borne diseases worldwide (Scallan et al. 2011). 
Various studies demonstrated that certain bacterial factors are essential for the pathogenesis of $C$. jejuni including the motility and adherence to intestinal mucosa, capability of the bacteria to invade enterocytes as well as toxin production (Datta et al., 2003 and Dasti et al., 2010).

Some genes have been recognized as responsible for the expression of pathogenicity such as flaA, virB11 and invasion associated markers (iam) genes which are genetic markers for $C$. jejuni (Nuijten et al., 2000).

The main objectives of this study wereto investigate the presence of Campylobacter jejuni in broiler chickens in the area of study and detection of their genes that have been recognized as responsible for the expression of pathogenicity.

\section{Materials ANd Methods}

Ethical Approval: This study has been approved by the animal rights and ethical use committee of Assiut University.

Area of Study: The study was conducted in Assiut and New Valley provinces. This area of study represents about one half from the total Egypt area.

\section{PM Examination}

Samples Collection: A total of 200 samples were collected from 100broiler chickens (dead and live birds suffering from diarrhea). The age of birds was 3-6 weeks. The samples were divided into 100 intestinal samples and 100liver samples. This study was performed during the period between March and September 2016.Samples were sent to the laboratory and prepared for microbiological and molecular examinations.

Samples Preparation: Samples were prepared as the following; Ten grams from each sample were weighted under complete aseptic conditions, and transferred into sterile polyethylene bag containing $90 \mathrm{ml}$ of sterile $0.1 \%$ peptone water (Oxoid). Samples were blended in a stomacher (Lab-blender, 400) for one minute to provide $10^{-1}$ dilution.

Microbiological Examination: Total bacterial count was performed by adding $0.1 \mathrm{ml}$ of each

Table1. Primers sequences, target genes, amplicon sizes and annealing temperature of PCR reactions

\begin{tabular}{|c|c|c|c|c|}
\hline $\begin{array}{l}\text { Target } \\
\text { gene }\end{array}$ & $\begin{array}{l}\text { Primers sequences } \\
\quad\left(5^{`} \text { to } 3^{`}\right)\end{array}$ & $\begin{array}{l}\text { Amplified } \\
\text { segment } \\
\text { (bp) }\end{array}$ & Annealing & Reference \\
\hline \multirow[t]{2}{*}{ flaA } & AATAAAAATGCTGATAAAACAGGTG & \multirow[t]{2}{*}{855} & \multirow[t]{2}{*}{$53^{\circ} \mathrm{C}$} & \multirow[t]{4}{*}{ Datta et al., 2003} \\
\hline & TACCGAACCAATGTCTGCTCTGATT & & & \\
\hline \multirow[t]{2}{*}{ VirB11 } & TCTTGTGAGTTGCCTTACCCCTTTT & \multirow[t]{2}{*}{494} & \multirow[t]{2}{*}{$53^{\circ} \mathrm{C}$} & \\
\hline & CCTGCGTGTCCTGTGTTATTTACCC & & & \\
\hline iam & $\begin{array}{l}\text { GCGCAAATATTATCACCC } \\
\text { TTCACGACTACTACTATGCGG }\end{array}$ & 518 & $46^{\circ} \mathrm{C}$ & Wieczorek et al., 2012 \\
\hline
\end{tabular}

dilution to the following media in duplicate: Standard plate count agar (Oxoid) using drop technique. The plates were kept in the incubator at $35^{\circ} \mathrm{C}$ for 24 hours. Plates with distinct colonies counted between 30-300 colony were estimated as Colony Forming Units (CFU).

The isolation of $C$. jejuni was performed by streaking the dilutions on blood agar medium (Preston agar) (Oxoid), then incubated microaerobically at $42^{\circ} \mathrm{C}$ for $24-48$ hours.

All the isolates were picked up and preserved on nutrient agar (Oxoid) and examined microscopically by Gram's stain to demonstrate the morphological arrangement and staining characters. Pure cultures of the isolates were biochemically identified according to Quinn $\boldsymbol{e t}$ al., (1994). Ten pure positive isolates of $C$. jejuni were selected for further enterotoxins and pathogenicity gene identification by PCR.

PCR Protocol: DNA was extracted from $C$. jejuni isolates from chicken samples using the QIA amp DNA Mini kit (Qiagen, Germany, $\mathrm{GmbH}$ ) with modifications from the manufacturer's recommendations. In brief, 200 $\mu l$ of the sample suspension was incubated with $10 \mu \mathrm{l}$ of proteinase $\mathrm{K}$ and $200 \mu \mathrm{l}$ of lysis at $56^{\circ} \mathrm{C}$ for 10 minutes. After incubation, $200 \mu \mathrm{l}$ of $100 \%$ ethanol was added to the lysate. The sample was then washed and centrifuged following the manufacturer's recommendations. Nucleic acid was eluted with $100 \mu \mathrm{l}$ of elution buffer provided in the kit. Primers used were supplied from (Biobasic, Canada) as showed in table (1). Primers were utilized in a $25 \mu 1$ PCR reaction containing $12.5 \mu \mathrm{l}$ of $2 \mathrm{X}$ DreamTaq Green Mastermix kit (Fermentas, Germany), $1 \mu \mathrm{l}$ of each primer of 10 pmol concentration, $4.5 \mu \mathrm{l}$ of water, and $6 \mu 1$ of DNA template. The reactions were conducted in applied biosystem 2720 thermal cycler. The thermal cycle condition was used as initial denaturation at $94^{\circ} \mathrm{C}$ for 4 minutes, followed by 35 cycles of $94^{\circ} \mathrm{C}$ denaturation for 30 seconds, annealing (temperature differed as listed in table (1), for 30 seconds, and extension at $72^{\circ} \mathrm{C}$ for 45 seconds, followed by on cycle of final extension at $72^{\circ} \mathrm{C}$ for 5 minutes. 
The PCR products were separated by electrophoresis on 1.2\% agarose gel (Applichem, Germany, GmbH) in $1 \mathrm{X}$ TBE buffer at room temperature using gradients of $5 \mathrm{~V} / \mathrm{cm}$. For gel analysis, $10 \mu \mathrm{l}$ of PCR products were loaded in each gel slot and $100 \mathrm{bp}$ plus DNA Ladders (Qiagen, Germany, GmbH) were used to detect the fragment sizes. Control positive and control negative were used in each reaction. The gel was photographed by a gel documentation system (Alpha Innotech, Biometra).

\section{RESUltS}

1. PM lesions of dead broiler chickens were accumulation of fluid and gas or mucus in the intestines. Distention of intestines including ceca with watery fluid.

\section{Total Prevalence of C. Jejuni among} Broiler Chicken
Results showed that the total prevalence of $C$. jejuni among chicken samples was $25.5 \%$. The higher $C$. jejuni prevalence was in intestinal samples $26(26 \%)$ followed by liver samples 25 $(25 \%)$.

\section{Presence of Virb11, Flaa, and I am Virulence Genes among C. Jejuni Isolates from Chicken}

The prevalence of three main virulence genes $C$. jejuni from chicken intestinal (10 samples) and liver samples (10 samples) was reported in table (2) as following: the total prevalence of VirB11, flaA, and iam genes was $10 \%, 5 \%$, and $40 \%$, respectively. VirB11 gene was found in $2(20 \%)$ in intestinal samples. flaA gene was detected in $1(10 \%)$ only in intestinal samples. The highest rate was detected in iam gene by a percentage of $5(50 \%)$ in intestinal samples and in a lower rate in liver samples 3 (30\%).

Table2. Prevalence of three virulence genes of among C. jejuni isolates from chicken samples

\begin{tabular}{|c|c|c|c|}
\hline \multirow{2}{*}{ Samples } & \multicolumn{3}{|c|}{ Virulence C. Jejuni genes } \\
\cline { 2 - 4 } & VirB11 No (\%) & flaA No (\%) & Iam No (\%) \\
\hline Intestinal samples & $2(20 \%)$ & $1(10 \%)$ & $5(50 \%)$ \\
\hline Chicken liver & - & - & $3(30 \%)$ \\
\hline Total No=20 & $2(10 \%)$ & $1(5 \%)$ & $8(40 \%)$ \\
\hline
\end{tabular}

PCR amplification of the enterotoxins (VirB11) was 494 bp products of DNA extracted from $C$. jejuni, enterotoxins (iam): 518 bp molecular size.

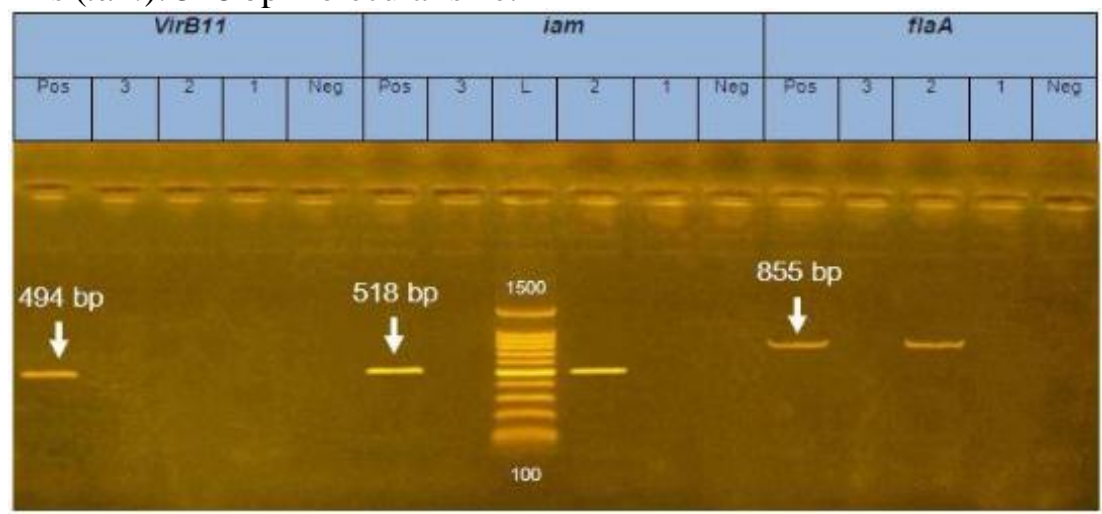

Figure1. Agarose gel electrophoresis of specific dose-dependent amplification of C. jejuni enterotoxins (VirB11, I am, flaA) of chicken samples.

PCR amplification of the enterotoxins (VirB11) 494 bp products of DNA extracted from C. jejuni, enterotoxins (iam): 518 bp molecular size ladder Enterotoxins (flaA): 855bp of C. jejuni isolates from chicken samples respectively.

\section{DISCUSSION}

Chicken are susceptible to various bacterial agents which may be caused by a lack of hygiene, extensive exposure to the microbial agents and being carriers of these micro-organisms due to their genetic immunity. C. jejuniis one of these agents that can be isolated from poultry. (Abd ElMalek et al., 2010).

ARC Journal of Animal and Veterinary Sciences
On commercial poultry farms, Campylobacter is rarely detected in birds less than 3 weeks of age. The reason for this lack of infection in young birds is unclear and may be related to various factors including the presence of maternally derived antibodies or differences in environmental or host-related conditions. Typically, the prevalence of Campylobacter rises as the birds grow and reaches the slaughter age for boiler chickens 
Campylobacter infections in poultry usually produce no clinical symptoms of illness under natural conditions. Although, some studies recorded that experimental challenge of young chickens with Campylobacter can produce clinical signs in the form of watery/mucoid/ bloody diarrhea, weight loss, or even mortality.

C. jejuni infect intestinal tract of several domestic poultry types frequently which be more sever in chicks which known as enter-invasive transient diarrhea resulting as watery droppings, hepatic focal necrosis, focal hemorrhage, jejunum distention or the absence of clinical signs. Infected bird shed $C$. jejuni after 2-3 weeks of infection (Shane, 2000). However, (Wagenaar et al. 2013) demonstrated that $100 \%$ of chickens infected asymptomatically by $C$. jejuni in their intestinal tracts and shading the organism through feces.

The prevalence of Campylobacter in commercial broilers ranges from 20-90\% (Shane, 2000 and Stern et al., 2001). In Canada and South America, the prevalence of Campylobacter in commercial broilers ranges from $45-48 \%$ and 20 96\%, respectively (Aho and Hirn, 1988 and Shane, 2000). In Europe, the proportion of commercial broiler flocks colonized with Campylobacter varies from $2.9 \%$ to more than 92\% (Bouwknegt et al., 2004; Evans and Sayers, 2000 and Hald et al., 2000) with the lowest flock prevalence $(2.9 \%)$ observed in Finland (Perko-Makela et al., 2002). In other regions, the prevalence of Campylobacter within commercial broiler flocks ranges from $13.6 \%$ to $87 \%$ in Africa (Cardinale et al., 2004), 24\% to 54\% in Asia (Newell and Fearnley, 2003). The obtained results of this study lay approximately in the middle area of the previous ratios.

While it is lower than the results of Saleha et al., 1998 (42\% in Australia) andthe prevalence rate of infected flocks is $44-59 \%$ (Nauta and Havelaar, 2008).

As well as, the average Campylobacter prevalence rate on chicken at retail is $57 \%$ (Humphrey et al., 2007).

Other study on the prevalence of Campylobacter incommercial broilers has shown that $85-98 \%$ of commercial broiler flocks were colonized by $C$. jejuni (Avrain et al., 2003).

The differences in the prevalence of $C$. jejuni could be attributed to the geographical area in this study. This study was conducted in a desert area and very hot and dry weather might be a determinant of the prevalence rate.

A variety of PCR assays targeting genus- or species-specific sequences have been developed to detect and identify Campylobacter from poultry.

Some potential genetic markers of bacterial virulence have been identified. FlaA gene involved in adhesion and colonization, virB11gene as pathogenic genes responsible for the expression of invasion and iam gene is associated with invasiveness and play a role in the transmission of Campylobacter and/or its adaptation to different hosts (Nuijten et al., 2000, Sanad et al., 2011; Young et al., 2007 and Dasti et al., 2010). In this study, the prevalence of VirB11 gene, flaA, and iam genes was 10\%, $5 \%$, and $40 \%$, respectively in chicken gut and liver. Results of VirB11 gene in chicken was higher than that reported by many authors; $6.1 \%$ (Wiseczorek et al., 2012), $7.3 \%$ (GonzalezHein et al., 2013) and 9.5\%. (Datta et al., 2003). The flaA gene was detected in 5\% of chicken gut, which was much lower than previous reports, which reached even $100 \%$ (Wiseczorek et al., 2012). The iam gene was detected in $40 \%$ of chicken liver and intestine which was higher than the previous study by Gonzalez-Hein et al., (2013) (6.2\%), whereas it was much lower than that detected by Wiseczorek et al., (2012) who recorded $53.8 \%$.

The detection of iam in $C$. jejuni isolated chickens, suggested a role for this marker in $C$. jejuni colonization. Moreover, it was proposed that the iam gene is not only essential for the colonization of the chicken gut but is also responsible for the induction of diarrhea (Korsak et al., 2004and Rozynek et al., 2005). The detection of high rates of virulence genes among chicken samples referred to the potential hazard infection in poultry flocks and for consumers by eating undercooked or improperly cooked chicken and their livers.

In conclusion, this survey revealed that poultry was often contaminated with $C$. jejuni that might represent a threat to poultry production. Furthermore, several strains were positive for the several putative virulence marker genes which may represent a further hazard for health. Therefore, adequate biosecurity measures should be in consideration during the chicken cycles. The equipment cleanliness and chemical disinfectants are warranted. 


\section{REFERENCES}

[1] Abdelmalek MF, Suzuki A, Guy C, UnalpArida A, Colvin R, Johnson RJ. and Diehl AM. 2010. Increased fructose consumption is associated with fibrosis severity in patients with nonalcoholic fatty liver disease. Nonalcoholic Steatohepatitis Clinical Research Network Hepatology. 51(6):1961-71. doi: 10.1002/hep. 23535.

[2] Aho, M. and J. Hirn. 1988. Prevalence of Campylobacter in the Finnish broiler chicken chain from the producer to the consumer. Acta Vet. Scand. 29: 451-462.

[3] Annan-Prah. A. and Jane, M. The mode of spread of Campylobacter jejuni l coli to broiler flocks. Journal of Veterinary Medicine 1988, 35, 11-18.

[4] Avrain, L., F. Humbert, R.L'Hospitalier, P. Sanders, C. Vernozy-Rozand and I. Kempf. 2003. Antimicrobial resistance in Campylobacter from broilers: association with production type and antimicrobial use. Vet. Microbiol. 96: 267-276.

[5] Bouwknegt, M., A.W. van de Giessen, W.D. Dam-Deisz, A.H. Havelaar, N.J. Nagelkerke and A.M. Henken. 2004. Risk factors for the presence of Campylobacter spp. in Dutch broiler flocks. Prev. Vet. Med. 62: 35-49.

[6] Cardinale, E., F. Tall, E.F. Gueye, M. Cisse and G. Salvat. 2004. Risk factors for Campylobacter spp. infection in Senegalese broiler-chicken flocks. Prev. Vet. Med. 64: 1525.

[7] Dasti JI, Tareen AM, Lugert R, Zautner AE. and Gross U.2010.Campylobacter jejuni: A brief overview on pathogenecity-associated factors and disease-mediating mechanism. International Journal of Medical Microbiology 300, 205-211.

[8] Datta S, Niwa H. and Itoh K. 2003.Prevalence of 11 pathogenic genes of Campylobacter jejuni by PCR in strains isolated from humans, poultry meat and broiler and bovine faeces. Journal of Medical Microbiology 52, 345-348.

[9] Evans, S.J. and Sayers, A.R. 2000. A longitudinal study of Campylobacter infection of broiler flocks in Great Britain. Preventive Veterinary Medicine 46: 209-223.

[10] Garcia Ana B., Madsen Anders L., Vigre Håkan, Integration of Epidemiological Evidence in a Decision Support Model for the Control of Campylobacter in Poultry Production, Agriculture 2013, 3, 516-535; doi: 10.3390/agriculture 3030516

[11] González-Hein G, Huaracán B, García P, and Figueroa G. 2013. Prevalence of virulence genes in strains of Campylobacter jejuni isolated from human, bovine and broiler. Braz $\mathrm{J}$ Microbiol. 10;44(4):1223-9.

[12] Hald, B., Wedderkopp, A. and Madsen, M. 2000. Thermophilic Campylobacter spp. in Danish broiler production: a cross-sectional survey and a retrospective analysis of risk factors for occurrence in broiler flocks. Avian Pathol. 29: 123-131.

[13] Humphrey, T. J., S. O'Brien and M. Madsen. 2007. Campylobacters as zoonotic pathogens: A food production perspective. Int. J. Food Microbiol. 117: 237-257.

[14] Korsak D, Dzierzanowska-Fangrat K, Popowskip J. and Rozynek E. 2004.Incidence of the virulence markers iam in Campylobacter jejuni and Campylobacter coli strains isolated from poultry carcases. Rocz Panstw Zakl Hig, 55:307-312.

[15] Nauta, M.J. and A.H. Havelaar. 2008. Riskbased standards for Campylobacter in the broiler meat chain. Food Control 19: 372-381.

[16] Newell, D.G. and C. Fearnley. 2003. Sources of Campylobacter colonization in broiler chickens. Appl. Environ. Microbiol. 69: 43434351.

[17] Nuijten, J., van den Berg, J., Formentini, I., van der Zeijst, A. and Jacobs, A. 2000.DNA rearrangements in the flagellin locus of an flaA mutant of Campylobacter jejuni during colonization of chicken ceca. Infect Immun 68, 7137-7140.

[18] Pearson, A. D. Greenwood, M., Healing, T. D., Rollins, D., Shahamat, M., Donaldson, J. and Colwell. R. R. Colonization of broiler chickens by waterborne Campylobacter jejuni. Applied Environmental Microbiology 1993, 59, 987-996.

[19] Perko-Makela, P., M. Hakkinen, T. Honkanen- Buzalski and M. L. Hanninen. 2002. Prevalence of Campylobacters in chicken flocks during the summer of 1999 in Finland. Epidemiol. Infect. 129: 187-192.

[20] Quinn, P.J., M.E. Carter, B.K. Markey and G. Carter, 1994. Clinical Veterinary Microbiology, Mosby yearbook Europe Ltd.

[21] Rosef, 0. and Kapperud, G. House flies (Musca domestica) as possible vectors of Campylobacter fetus subsp. jejuni. Applied Environmental Microbiology 1983, 45, 381-383.

[22] Rozynek E, Dzierzanowska-Fangrat K, Jozwiak P, Popowski J, Korsak D. and Dzierzanowska D. 2005. Prevalence of potential virulence markers in Polish Campylobacter jejuni and Campylobacter coli isolates obtained from hospitalized children and from chicken carcasses. J Med Microbiol, 54:615-619. 
[23] Saleha, A.A., G.C. Mead and A.L. Ibrahim, 1998. Campylobacter jejuni in poultry production and processing in relation to public health. J. World Poultry Sci. 54: 49-58.

[24] Sanad M, Kassem I, Liu Z, Lin J, Lejeune T. and Rajashekara G. 2011. Occurrence of the invasion associated marker (iam) in Campylobacter jejuni isolated from cattle. BMC Res Notes. Life Sci J;12(7):9-14].

[25] Scallan E1, Hoekstra RM, Angulo FJ, Tauxe RV, Widdowson MA, Roy SL, Jones JL, Griffin PM., 2011.Foodborne illness acquired in the United States--major pathogens. Emerg Infect Dis. 2011 Jan;17(1):7-15. doi: 10.3201/ eid1701.P11101.

[26] Shane, M. 2000.Campylobacter infection of commercial poultry. Rev. sci. tech. Off. int. Epiz., 19(2): 376-395.

[27] Shanker. S., Lee, A. and Sorrell, T. C. Horizontal transmission of Campylobacter jejuni amongst broiler chicks: experimental studies. Epidemiology of infection 1990, 104, 101-1 10.
[28] Stern, N.J., P.J. Fedorka-cray, J.S. Bailey, N.A. Cox, S.E. Craven, K.L. Hiett, M.T.Musgrove, S.R. Ladley, D. Cosby and G.C. Mead. 2001. Distribution of Campyloacter spp. In selected U.S. poultry production and processing operations. J. Food Prot.64:17051710.

[29] Wael Abdelrahman 2014: Fighting Campylobacter colonization in broiler chickens

[30] Wagenaar, A, French P. and Havelaar $\mathbf{H}$. 2013.Preventing Campylobacter at the source: why is it so difficult? Clin Infect Dis. 2013; 57(11):1600-6.

[31] Wieczorek K, Szewczyk R. and Osek J. 2012. Prevalence, antimicrobial resistance, and molecular characterization of Campylobacter jejuni and Campylobacter coli isolated from retail raw meat in Poland. Veterinarni Medicina. 57(6):293-299.

[32] Young KT, Davis LM. and DiRita VJ. 2007. Campylobacter jejuni: molecular biology and pathogenesis. Nature Reviews Microbiology 5, 665-679.

Citation: Mohamed Shaker Abdel Hafez, Nagwa Thabet El-Shraway. Campylobacter Jejuni Infection in Broilers. ARC Journal of Animal and Veterinary Sciences. 2019; 5(1):9-14. doi: dx.doi.org/10.20431/24552518.0501002 .

Copyright: (C) 2019 Authors. This is an open-access article distributed under the terms of the Creative Commons Attribution License, which permits unrestricted use, distribution, and reproduction in any medium, provided the original author and source are credited. 